\title{
Molecular Prevalence and Epidemiological Characteristics of Diarrheagenic $E$. coli in Children under 5 Years Old in the City of Koula-Moutou, East-Central Gabon
}

\author{
Rolande Mabika Mabika ${ }^{1}$, Sandrine Lydie Oyegue Liabagui ${ }^{2,3}$, Hilaire Kenguele Moundounga ${ }^{1}$, \\ Franck Mounioko1,4, Alain Souza1, Jean Fabrice Yala1* \\ ${ }^{1}$ Laboratoire de Biologie Moléculaire et Cellulaire, Équipe de Microbiologie (LABMC), Unité de Recherche Agrobiologie, \\ Université des Sciences et Techniques de Masuku (USTM), Franceville, Gabon \\ ${ }^{2}$ Unité d'Evolution, Epidémiologie et Résistance Parasitaire (UNEEREP), Centre Interdisciplinaire de Recherches Médicales de \\ Franceville (CIRMF), Franceville, Gabon \\ ${ }^{3}$ Laboratoire de Recherche en Immunologie, Parasitologie et Microbiologie (LRIPM), Ecole Doctorale Régionale d'Afrique \\ Centrale en Infectiologie Tropicale; Université des Sciences et Techniques de Masuku (USTM), Franceville, Gabon \\ ${ }^{4}$ Unité d'Ecologie des Systèmes Vectoriels (ESV), Centre Interdisciplinaire de Recherches Médicales de Franceville (CIRMF), \\ Franceville, Gabon \\ Email: *yalajeanfabrice@gmail.com
}

How to cite this paper: Mabika Mabika, R., Oyegue Liabagui, S.L., Kenguele Moundounga, H., Mounioko, F., Souza, A. and Yala, J.F. (2021) Molecular Prevalence and Epidemiological Characteristics of Diarrheagenic E. coli in Children under 5 Years Old in the City of Koula-Moutou, EastCentral Gabon. Open Journal of Medical Microbiology, 11, 157-175. https://doi.org/10.4236/ojmm.2021.113013

Received: June 7, 2021

Accepted: August 27, 2021

Published: August 30, 2021

Copyright $\odot 2021$ by author(s) and Scientific Research Publishing Inc. This work is licensed under the Creative Commons Attribution International License (CC BY 4.0).

http://creativecommons.org/licenses/by/4.0/ (c) (i) Open Access

\begin{abstract}
Background and Purpose: Diarrhoeagenic E. coli (DEC) is one of the germs responsible for childhood diarrhea in developing countries. This study aims at determining the prevalence of the five main pathotypes of DEC isolated from faeces of children under five years old with diarrhea or not, living in the city of Koula-Moutou. Methodology: Isolates of E. coli were phenotypically screened on chromID ${ }^{\mathrm{TM}}$ agar and molecularly by multiplex PCR to detect the presence of enteroaggregative E. coli (EAEC), enteropathogenic E. coli (EPEC), enterotoxigenic E. coli (ETEC), enterohemorragic E. coli (EHEC) and enteroinvasive E. coli (EIEC). The evaluation of their sensitivity to $12 \beta$-lactam antibiotic molecules was carried out by Kirby Bauer method. This method has also made it possible to characterize phenotypically the different $\beta$-lactamases produced. Results and Conclusion: Overall, at least one DEC pathovar was detected in the $63 \mathrm{E}$. coli strains with phenotypic and molecular frequencies of $63.5 \%$ and $68.5 \%$ respectively. Thus, ETEC (28.3\%) and EHEC (28.3\%) were the most frequent DEC in diarrheal isolates. ETEC/EHEC hybrid was recorded in both groups with rates of $7.5 \%$ in diarrheal cases and $10.0 \%$ for controls. The results showed produced carbapenemase type $\beta$-lactamases (31.7\%), followed by ESBL (24.4\%) and few produced high level penicillinases
\end{abstract}


(4.9\%). The DEC, in particular ETEC and EHEC are most likely the epidemiological agents responsible for childhood diarrhea in this study.

\section{Keywords}

Diarrhea, Children, Diarrheagenic E. coli, $\beta$-Lactamases, Multiplex PCR

\section{Introduction}

Diarrhea remains the leading source of morbidity and mortality in children under 5 years of age worldwide with approximately 760,000 annual deaths [1] [2]. According to the World Health Organization, diarrheal infections are the second leading cause of death in children under 5 years of age after the Human Immunodeficiency Virus [3]. However, diarrheagenic Escherichia coli (DEC) is the main enteric pathogen involved in diarrheal disease [4] [5]. DEC strains are mainly responsible for causing gastroenteritis in children and account for $30 \%$ to $40 \%$ of childhood diarrhea episodes reported in developing countries [6]. In addition, recent work conducted in Africa, Spain, India, China, Mexico and Japan have revealed the evolution of the atypical and hybrid variants of the DEC strains, but also that these variants had a higher severity of infection than those of typical DEC [7] [8]. Moreover, DEC are involved in many infections due to their various virulence factors and pathogenicity mechanisms. Thus, they pose a serious public health problem [7] particularly among children and adults of developing countries.

In addition, the frequency of DEC is often high in Africa and varies with the geographical area. Indeed, in Nigeria, prevalences of $18.4 \%$ and $35 \%$ were respectively recorded in Abuja, [9] and Ile-Ife [10]. Whereas, DEC recorded prevalences were $37.5 \%$ in India [11], 16.4\% in Southeast China, $21.4 \%$ in Eastern Iran and 23.3\% in Northeast Mexico [12] [13] [14]. In the United States, approximately 20,781 cases of food-borne illness are caused each year by DEC, with a mortality rate of $0.8 \%$ [15].

These very large groups of $E$. coli strains, which have different pathogenicity mechanisms in diarrheal episodes, are classified into six (6) major pathotypes. According to numerous studies, we distinguish enteropathogenic E. coli (EPEC), enterohemorrhagic $E$. coli (EHEC) including shiga toxin producing $E$. coli, enteroinvasive E. coli, enterotoxinogenic E. coli (ETEC), Enteroaggregative E. coli (EAEC) and diffuse adherence E. coli (DAEC) [16] [17].

In Africa and particularly in Gabon, these pathogens are not routinely investigated. Moreover, epidemiological data on DEC is still rare and whenever E. coli strains are isolated and identified, the pathotypes are not identified. Therefore, this study was undertaken to determine phenotypically and genotypically the prevalence of diarrheagenic $E$. coli isolated from childhood diarrheal feces at the Paul Moukambi Regional Hospital Center in Koula-Moutou, East-central Gabon. 


\section{Methodology}

\subsection{Study Design and Population and Clinical Strains}

Stool samples from 132 children aged 0 to 5 years old with acute diarrheal or not were collected in the city of Koula-Moutou over a two-year period (May 2016Fevrier 2018). Samples were screened for Enterobacteria and parasites. Among the various presumptive pathogens cryopreserved in the Cellular and Molecular Biology Laboratory (LABMC), 63 strains of $E$. coli formed the biological material, of which 53 strains were isolated from children with diarrhea and 10 from healthy children (control). The details of the various characteristics and criteria of the patients recruited were previously described [18].

\subsection{Characterization of $E$. coli Isolates}

\section{Phenotypic research of presumptive strains of $E$. coli O157:H7}

Phenotypic research for enterohemorrhagic E. coli (EHEC) serotype O157: H7 in diarrheal and normal stool sample was carried out on the agar medium chromIDTM O157:H7. The young colonies of the E. coli strains were subcultured on the same medium and incubated at $37^{\circ} \mathrm{C}$ for $18-24$ h. E. coli $\mathrm{O} 157: \mathrm{H} 7$ colonies gave the characteristic Green color.

Molecular identification and classification of diarrheagenic E. coli (DEC)

All strains of $E$. coli were analyzed as described in previous studies with some modifications [19] [20] and the summary description is detailed below.

\section{DNA Extraction}

Genomic DNA was extracted bacterial colonies as described below. Colonies were resuspended in $200 \mu \mathrm{l}$ of $1 \mathrm{X}$ DNA/RNA reagent (Biolabs New England). The bacterial suspensions were lyzed in $200 \mu \mathrm{l}$ of $2 \mathrm{X}$ lysis buffer (1\% SDS, 20 $\mathrm{mM} \mathrm{Nacl}, 20 \mathrm{mM}$ Tris $\mathrm{pH} 8,20 \mathrm{mM}$ EDTA) and $40 \mu \mathrm{l}$ of $100 \mu \mathrm{g} / \mathrm{ml}$ proteinase $\mathrm{K}$ solution. Then, the preparations were incubated in a heat block at $56^{\circ} \mathrm{C}$ for $1 \mathrm{~h}$. The resulting lysates obtained were centrifuged at $12,000 \mathrm{rpm}$ for $10 \mathrm{~min}$. Then, released DNA was precipitated by adding $350 \mu \mathrm{l}$ of isopropanol and $50 \mu \mathrm{l}$ of sodium acetate at $3 \mathrm{M}$ and centrifuging at $14,000 \mathrm{rpm}$ for $15 \mathrm{~min}$. The DNA containing pellets were resuspended in $70 \mu \mathrm{L}$ of ultra-pure water and used later for PCR amplification.

\section{Multiplex Polymerase Chain Reaction}

E. coli pathogens (EAEC, EIEC, EHEC, EPEC, ETEC and STEC) were identified using primers listed in the Table 1.

PCR was performed in a final volume of $20 \mu$ containing $1 \mathrm{X}$ master mix PCR multiplex (Qiagen ${ }^{\circledR}$ Multiplex PCR Kit), 1X Q-Solution (Qiagen ${ }^{\circledR}$ Multiplex PCR Kit) and $2 \mu$ of genomic DNA diluted 1000 fold, and $0.3 \mu \mathrm{M}$ of each primer set. The amplification was carried out in a thermocycler (Bio-RAD, T100TM, USA) under the program described by Vilchez et al. [20]. The E. coli strains carrying both eae $A$ and stx genes were considered as STEC O157: H7 (Table 1). On the other hand, those carrying only the eae $A$ gene were considered as atypical EPEC (aEPEC). While those carrying the $b f p A$ gene or both (eaeA and $b f p A$ ) were 
Table 1. Primers used for the detection of the various DEC.

\begin{tabular}{|c|c|c|c|c|c|}
\hline Type of DEC & Genes & Primer & Primer sequence $\left(5^{\prime}-3^{\prime}\right)$ & Size (bp) & References \\
\hline \multirow[t]{4}{*}{ ETEC } & \multirow[b]{2}{*}{ eltB } & LT-F & TCTCTATGTGCATACGGAGC & \multirow[b]{2}{*}{322} & \multirow[b]{2}{*}{ [20] } \\
\hline & & LT-R & CCATACTGATTGCCGCAAT & & \\
\hline & \multirow{2}{*}{ estA } & ST-F & GTCAAACCAGTA(G/A)GGTCTTCAAAA & \multirow{2}{*}{147} & \multirow{2}{*}{ [20] } \\
\hline & & ST-R & CCCGGTACA(G/A)GGAGGATTACAACA & & \\
\hline \multirow[t]{4}{*}{ EHEC } & \multirow[b]{2}{*}{ vit1 } & VT1-F & GAAGAGTCCGTGGGATTAC & \multirow[b]{2}{*}{130} & \multirow[b]{2}{*}{ [20] } \\
\hline & & VT1-R & AGCGATGCAGCTATTAATAA & & \\
\hline & \multirow{2}{*}{ vit2 } & VT2-F & ACCGTTTTTCAGATTTT(G/A)CACATA & \multirow{2}{*}{298} & \multirow{2}{*}{ [20] } \\
\hline & & VT2-R & TACACAGGAGCAGTTTCAGACAGT & & \\
\hline \multirow[t]{4}{*}{ EPEC } & \multirow{2}{*}{$e a e A$} & eae-F & CACACGAATAAACTGACTAAAATG & \multirow{2}{*}{376} & \multirow{2}{*}{ [20] } \\
\hline & & eae- $\mathrm{R}$ & AAAAACGCTGACCCGCACCTAAAT & & \\
\hline & \multirow[b]{2}{*}{$b f p A$} & bfpA-F & TTCTTGGTGCTTGCGTGTCTTTT & \multirow[b]{2}{*}{367} & \multirow[b]{2}{*}{ [20] } \\
\hline & & bfpA-R & TTTTGTTTGTTGTATCTTTGTAA & & \\
\hline \multirow[t]{2}{*}{ EAEC } & \multirow{2}{*}{ pCVD432 } & EA-F & CTGGCGAAAGACTGTATCAT & \multirow{2}{*}{630} & \multirow{2}{*}{ [20] } \\
\hline & & EA-R & AAATGTATAGAAATCCGCTGTT & & \\
\hline \multirow[t]{2}{*}{ EIEC } & \multirow[b]{2}{*}{ ial } & SHIG-F & CTGGTAGGTATGGTGAGG & \multirow[b]{2}{*}{320} & \multirow[b]{2}{*}{ [20] } \\
\hline & & SHIG-R & CCAGGCCAACAATTATTTCC & & \\
\hline \multirow[t]{4}{*}{ Shigella ipaH } & \multirow{2}{*}{$i p a H$} & ipaH-F & GTTCCTTGACCGCCTTTCCGATACCGTC & \multirow{2}{*}{619} & \multirow{4}{*}{ [21] } \\
\hline & & ipaH-R & GCCGGTCAGCCACCCTCTGAGAGTAC & & \\
\hline & \multirow{2}{*}{$e a e A$} & eae-F & CACACGAATAAACTGACTAAAATG & & \\
\hline & & eae-R & AAAAACGCTGACCCGCACCTAAAT & 376 & \\
\hline & & $\mathrm{X} 1-\mathrm{F}$ & CAGTTAATGTGGTGGCGAAG & & \\
\hline & stXI & $\mathrm{X} 1-\mathrm{R}$ & CTGCTAATAGTTCTGCGCATC & 894 & \\
\hline & & $\mathrm{X} 2-\mathrm{F}$ & CTTCGGTATCCTATTCCCGG & & {$[22]$} \\
\hline & $\operatorname{stX} 2$ & $\mathrm{X} 2-\mathrm{R}$ & GGATGCATCTCTGGTCATTG & $4 / 8$ & \\
\hline
\end{tabular}

identified as typical EPEC (tEPEC). The amplicons were separated on a $1.5 \%$ $(\mathrm{m} / \mathrm{v})$ agarose gel for $2 \mathrm{~h}$ at $300 \mathrm{~V}$. The $100 \mathrm{bp}$ ladder was used as a molecular weight marker (100 bp; Qiagen ${ }^{\circledR}$, GelPilot ${ }^{\circledR}$ ). The DNA bands were visualized and photographed under UV light following the gel staining with ethidium bromide.

Diversity of $\beta$-lactamases produced by characterized diarrheagenic $E$. coli

The Antibiogram profile was determined by the agar dilution method according to the reference technique of diffusion in agar medium (Mueller-Hinton) against 12 specific antibiotics of the $\beta$-lactam family [23] to determine their sensitivity profiles and categorize phenotypically the different $\beta$-lactamases likely to be produced by the DEC. The detection of extended-spectrum $\beta$-lactamase isolates (ESBL) was not only done by screening on MacConkey agar supplemented with concentrated Cefotaxime at $2 \mathrm{mg} / \mathrm{ml}$; but also, by the double disc synergy test 
(phenotypic confirmation test for ESBL) according to the standards of the Antibiogram Committee of the French Society of Microbiology v.2.0. Mai 2019.

\subsection{Statistical Analyzes}

Statistical analyzes were performed using $\mathrm{R}$ software version 3.2.2. The significance threshold set was 5\%. Fisher's exact test compared the prevalence of DEC isolates between the two population categories.

\section{Results}

\subsection{Phenotypic Detection of E. coli 0157:H7}

The characterization of the $63 \mathrm{E}$. coli strains isolated from children with diarrhea and controls was carried out phenotypically by looking for serovar O157: H7 and genotypically by looking for genes of interest. The results of the phenotypic detection of the E. coli $\mathrm{O} 157: \mathrm{H} 7$ strains are presented in Figure 1.

In total, $63.5 \%$ (40/63) of the $E$. coli isolates were phenotypically positive for the serotype $\mathrm{O} 157: \mathrm{H7}$, of which $61.9 \%$ were detected in diarrheic children and $1.6 \%$ in healthy ones. In diarrhea cases, out of 53 E. coli strains screened, 39 strains $(74 \%)$ were presumptive of the O157:H7 phenotype compared to 1 strain $(10 \%)$ in control cases (see Figure 1).

\subsection{Genotypic Detection of DEC}

Of the 63 strains of E. coli, the detection rate of genes of interest for DEC characterization was $68.3 \%(43 / 63)$. The various pathovars thus detected after PCR screening are presented in Table 2.

The results of Table 2 revealed that $67.9 \%(36 / 53)$ of the isolates from diarrheal cases were positive DEC against 10\% (1/10) of the isolates for the control

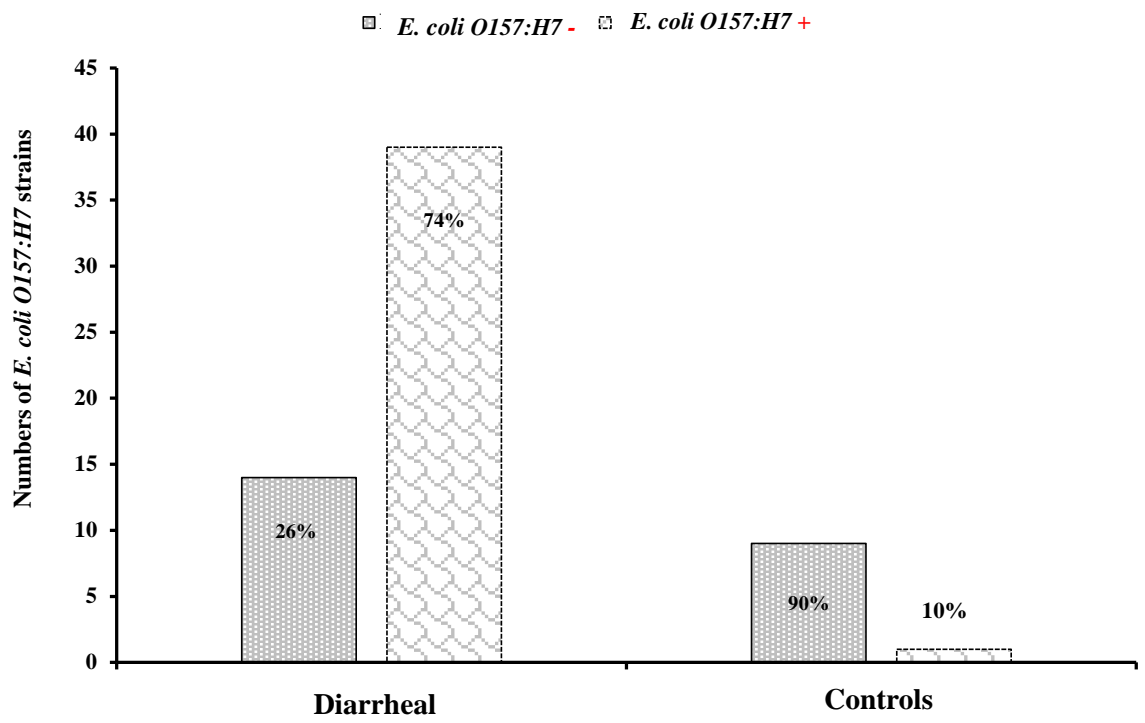

Figure 1. Proportion of E. coli O157:H7 strain in children with and without diarrhea (control group). 
Table 2. Frequency of detection of DEC in diarrheal cases and controls in the city of Koula-Moutou.

\begin{tabular}{|c|c|c|c|c|}
\hline \multirow[b]{2}{*}{ Type of DEC } & \multicolumn{2}{|c|}{$\mathrm{N}(\%)$ isolated $E$. coli in cases and controls } & \multirow[b]{2}{*}{ OR } & \multirow[b]{2}{*}{$\begin{array}{c}\text { Fisher's exact tes } \\
\text { p-value }\end{array}$} \\
\hline & $\begin{array}{l}\text { E. coli isolated from } \\
\text { diarrheic children } \\
\quad(n=53)\end{array}$ & $\begin{array}{l}\text { E. coli isolated from } \\
\text { healthy children } \\
(\mathrm{n}=10)\end{array}$ & & \\
\hline Mono-detection & $36(67.9)$ & $1(10.0)$ & 16.76 & 0.001 \\
\hline EAEC & $2(3.8)$ & $0(0.0)$ & NA & NA \\
\hline EHEC & $15(28.3)$ & $1(10.0)$ & 3.18 & 0.4 \\
\hline EPEC & $4(7.5)$ & $0(0.0)$ & NA & NA \\
\hline ETEC & $15(28.3)$ & $0(0.0)$ & NA & NA \\
\hline EIEC & $0(0.0)$ & $0(0.0)$ & NA & NA \\
\hline STEC & $0(0.0)$ & $0(0.0)$ & NA & NA \\
\hline Shigella ipaH & $0(0.0)$ & $0(0.0)$ & NA & NA \\
\hline Co-detection & $5(9.4)$ & $1(10.0)$ & 1.36 & 1 \\
\hline ETEC/EHEC & $4(7.5)$ & $1(10.0)$ & 0.54 & 0.5 \\
\hline EAEC/ETEC & $1(1.9)$ & $0(0.0)$ & NA & NA \\
\hline
\end{tabular}

OR: odds ratio; NA: not applicable.

group for mono-detection. In addition, Fisher's exact test showed a significant difference between the two groups $(p=0.001)$. Among the different DEC detected in diarrheic children, ETEC and EHEC pathotypes were the most common with a detection rate of $28.3 \%$ each. The least representative pathotype were the EPEC and the EAEC with frequencies of $7.5 \%$ and $3.8 \%$, respectively. While for the control group, the only type of DEC identified was the EHEC pathotype with a frequency of $10 \%$. On the other hand, no significant difference was observed between the cases and the control group for the type of DEC $(\mathrm{p}=0.4)$. Furthermore, no strain is STEC or producer of the virulence factor of Shigella ipaH (Table 2).

The co-detection of DEC pathogroups was also recorded in the two groups with an overall prevalence of $9.4 \%$ for diarrheal cases and $10 \%$ for the control group without any significant difference $(\mathrm{p}=1.0)$ (see Table 2) ETEC/EHEC hybrids were detected in $7.5 \%$ of cases of diarrhoea and $10.0 \%$ for controls with no significant difference $(\mathrm{p}=0.5)$. The detection of EAEC/ETEC hybrids was found only in diarrheic cases with a rate of $1.9 \%$.

\subsection{Different Genes of Intra-Pathotype Determinants and Classification of DEC}

The classification of DEC into standard pathovars was carried out by specific research into their virulence determinants, the profile of which is presented in Table 3 .

Table 3 analysis revealed a heterogeneity in the virulence factors of the four 
Table 3. Frequency of detection of selected virulence factors within DEC.

\begin{tabular}{|c|c|c|c|c|}
\hline Pathotypes & $\mathrm{N}=43$ & virulence genes & Number of strains (n) & Percentage (\%) \\
\hline \multirow[t]{2}{*}{ EAEC } & 2 & & & \\
\hline & & $E A$ & 2 & 100.0 \\
\hline \multirow[t]{4}{*}{ EHEC } & 16 & & & \\
\hline & & vit1 & 2 & 12.5 \\
\hline & & vit2 & 11 & 68.8 \\
\hline & & vit1-vit2 & 3 & 18.8 \\
\hline EPEC & 4 & & & \\
\hline \multirow{2}{*}{ tEPEC } & & $b f p A$ & 3 & 75.0 \\
\hline & 4 & $b f p A+e a e$ & 1 & 25.0 \\
\hline aEPEC & 0 & eae & 0 & 0.0 \\
\hline \multirow[t]{3}{*}{ ETEC } & 15 & & & \\
\hline & & $S T$ & 12 & 80.0 \\
\hline & & $L T$ & 3 & 20.0 \\
\hline \multirow[t]{3}{*}{ ETEC/EHEC } & 4 & & & \\
\hline & & vit1-ST & 3 & 75.0 \\
\hline & & vit2-ST & 1 & 25.0 \\
\hline \multirow[t]{2}{*}{ EAEC/ETEC } & 1 & & & \\
\hline & & $E A-L T$ & 1 & 100.0 \\
\hline
\end{tabular}

tEPEC: EPEC typical; aEPEC: EPEC atypical.

(4) pathotypes within the different $E$. coli strains. The EHEC pathogen was mainly carrier of the vit 2 verotoxin gene $(68.8 \%)$, followed by the combination of vit1 and vit2 verotoxin genes (18.8\%) and finally those carrying the vit1 gene (12.5\%). Eighty percent $(80.0 \%)$ of ETEC were carriers of the thermostable $S T$ toxin genes versus $20.0 \%$ for the thermolabile LT toxin genes. Finally, for the EPEC pathotype, only typical EPEC were recorded, $75.0 \%$ of which possesses the Bfp determinant gene while 25\% the Bfp and Eae determinant genes (see Table 3). Regarding $E$. coli hybrid pathovars, the association of EA- $L T$ virulence genes (100\%) was the most common for EAEC/ETEC, followed by the association of the vit1-ST determinant genes (75.0\%) for ETEC/EHEC.

\subsection{Classification of Diarrheagenic E. coli According to $\beta$-Lactamases}

Among the 41 characterized diarrheagenic $E$. coli strains, a classification of the $\beta$-lactamases they produce was performed, the results are presented in Table 4.

The results of Table 4 revealed a diversity of $\beta$-lactamases produced by DEC. Thus, it appeared that the EAEC of this study produced the association of ESBL + Case and Carbases enzymes with frequencies of 50\% each. The EHEC produce 
Table 4. Diarrheagenic E. coli and their $\beta$-lactamase enzyme diversity.

\begin{tabular}{cccccccc}
\hline Type of DEC & $\begin{array}{c}\text { Number of } \\
\text { strains }\end{array}$ & $\begin{array}{c}\text { PHN } \\
\mathrm{n}(\%)\end{array}$ & $\begin{array}{c}\text { PRI } \\
\mathrm{n}(\%)\end{array}$ & $\begin{array}{c}\text { ESBL } \\
\mathrm{n}(\%)\end{array}$ & $\begin{array}{c}\text { Case } \\
\mathrm{n}(\%)\end{array}$ & $\begin{array}{c}\text { ESBL + Case } \\
\mathrm{n}(\%)\end{array}$ & $\begin{array}{c}\text { Carbase } \\
\mathrm{n}(\%)\end{array}$ \\
\hline EAEC & 2 & - & - & - & - & $1(50.0 \%)$ & $1(50.0 \%)$ \\
EHEC & $\mathbf{1 5}$ & $4(26.7)$ & - & $3(18.8)$ & $1(6.3)$ & $4(25.0)$ & $3(18.8)$ \\
EPEC & 4 & - & - & - & - & - & $4(100.0)$ \\
ETEC & $\mathbf{1 5}$ & - & $2(13.3)$ & $6(40.0)$ & $2(13.3)$ & $1(6.7)$ & $4(26.7)$ \\
ETEC/EHEC & $\mathbf{3}$ & $1(25.0)$ & - & $1(25.0)$ & $1(25.0)$ & - & $1(25.0)$ \\
EAEC/ETEC & $\mathbf{1}$ & - & - & - & - & $1(100.0)$ & - \\
Total & $\mathbf{4 1}$ & $\mathbf{5 ( 1 2 . 2 )}$ & $\mathbf{2 ( 4 . 9 )}$ & $\mathbf{1 0 ( 2 4 . 4 )}$ & $\mathbf{4 ( 9 . 8 )}$ & $\mathbf{7 ( 1 7 . 1 )}$ & $13(31.7)$ \\
\hline
\end{tabular}

PHN: high-level penicillinases; PRI: inhibitor resistant penicillinase; Case: cephalosporinase; ESBL: extended spectrum $\beta$-lactamase; Carbase: carbapenemase; EAEC: enteroaggregative E. coli; EHEC: enterohemorragic E. coli; EPEC: enteropathogenic E. coli; ETEC: enterotoxinogic E. coli.

mostly PHN (26.7\%) and the association ESBL + Case (26.7\%). These strains also produced ESBL + Carbase, and Case with frequencies of $18.8 \%$ and $6.3 \%$, respectively. All EPEC were producers of Carbases and the ETEC in this study were mostly producers of ESBL (40.0\%). The other isolates in this group produced $26.7 \%$ of Carbases, $13.3 \%$ of each PRI and Case, and $6.7 \%$ of ESBL + Case (see Table 4). ETEC and EHEC hybrids produced the enzymes of the PNH, ESBL, Case and Carbase types with the same frequency (25.0\%). Whereas, the only EAEC/ETEC hybrid only produced the association ESBL + Case (100.0\%).

\section{Discussion}

The objective of this study was to determine the epidemiological profile of $E$. coli pathovars isolated from stool samples of children aged 0 - 5 years with acute diarrhea or not living in the city of Koula-Moutou. Diarrheagenic E. coli (DEC) in childhood diarrhea in developing and developed countries has a heavy burden on the morbidity and mortality rates of this class age.

The high frequency of the different DEC pathovars found in this study, both phenotypically $(63.5 \%)$ and molecularly $(68.3 \%)$ is similar to that reported by d'Iijima et al., in Kenya [24], Darbandi et al. in Iran [25] and higher than that reported in other developing countries [14] [26]. The impact of these results clearly highlights the public health threat posed by diarrheal diseases due to DEC for children in these developing countries [14]. Particularly, the serogroup O157, which is part of serogroup O111, is the most frequently isolated and often associated with one or more of these pathotypes [27] [28]. This health threat is especially higher in rural and even urban areas due to poor hygiene conditions. Indeed, the many rivers in the city of Koula-Moutou, are generally used for domestic needs by local populations. However, their pollution by human and animal wastes or other forms of pollution such as poor maintenance of public water pumps are all risk factors for transmission of these pathogens [29] [30]. Currently, an increase in these DEC is described in particular by the phenomenon of 
cross-transmission relating to environmental factors such as the contamination of irrigation water [16] [31].

In this study, the results obtained underline the importance of ETEC (28.3\%) and EHEC (28.3\%) as the dominant agents of DEC responsible for childhood diarrhea in the city of Koula-Moutou as reported in the literature [31]. These results are different from those reported by other authors in the cities of Libreville and Lambaréné in Gabon [33] [34]. This observed difference could be explained by the spatio-temporal variability of the epidemiological character concerning the infectious etiologies of childhood diarrhea [1] [35]. The prevalence of ETEC recorded is similar to that reported in Nicaragua among children in the same age group which was $27.9 \%$ [20]. This could be explained by the fact that most $E$. coli isolates were from children over 6 months of age who loses the immunity [antibodies] transmitted through breast milk overtime [9]. Indeed, it has been stressed in the literature that breast milk could give infants protection against infectious diseases [36]. In addition, the practice of exclusive breastfeeding during the first 6 months or up to the 11th month of birth is an effective preventive means against child mortality related to diarrheal diseases [37]. This prevalence was higher than the one reported among children in Malawi (10.6\%) [38], in a rural area of Egypt (18.9\%) [39], in Kenya (7.2\%) [32], in Northern India (6\%) [40] and Perou (4\%) [41].

Although previous studies have described a low prevalence or absence of EHEC in diarrheal infections in developing countries [20] [42] [43], their prevalence was significant in this study $(28.3 \%)$ and they all produced verocytoxins. These results corroborate the rapid expansion of the involvement of this group of DEC in diarrheal diseases in children [44] [45]. This expansion could probably be favored by the presence of numerous rivers used by populations prone to human and/or animal faecal contamination.

The cases of detection of EAEC in our study was very low compared to current data [43] [45] [46]. Indeed, a prevalence of 3.8\% was recorded in this study which is lower than the prevalences of $34.4 \%$ reported by Onanuga et al., in Nigeria [9], 14.7\% in South India [45], 14\% in Tehran [22], 9.5\% in Burkina Faso [26] and $7.86 \%$ in Lambaréné, Gabon [33]. However, it is comparable to that found in India (3.8\%) [47] and Iran (4.0\%) [25]. Their isolation in this study could corroborate the fact that these pathogens are considered as emerging pathogens currently in cases of diarrheal diseases especially in developing countries [9] [26]. Also, they could be involved in acute and chronic diarrhea in all age groups [7]. Their frequent detection could be linked to their ubiquitous character of any environment that could be favored by poor hygiene conditions in developing countries [26] [47]. Finally, they are associated with diarrhea known as traveler's diarrhea in developed and developing countries [15] [46].

The frequency of EPEC cases (7.5\%) in this study is similar to that recorded in other studies in developing countries [47] [48]. However, the latter is higher than that recorded in Lambaréné (Gabon) where no EPEC isolates were found 
[33], However, our EPC frequency was lower than the frequencies of $57.7 \%$ and $50.0 \%$ reported respectively by Koko et al., in Libreville, the capital city of Gabon, and, Zhou et al., in China [34] [46], reflecting the epidemiological variability of pathogens. In addition, these EPEC isolates could also be one of the very important pathogens in children with diarrhea in developing countries even though other pathogens are currently involved [49] [50].

Ability to acquire virulence genes by horizontal transfer in DEC to other pathogens leads to the development of hybrids or mixed virulence profiles [8]. Thus, the hybrid ETEC/EHEC is one of the peculiarities of this work corroborating many studies [11] [51]. This result could be explained by the fact that these two types of DEC are the most common germs by their mode of transmission. Indeed, these are transmitted through the ingestion of contaminated water and food, in addition to the geo-epidemiological variability of DEC [26] [52] [53]. Although poorly identified, EAEC/ETEC hybrid strains were also recorded in Burkina Faso and Kenya with similar prevalence [26] [43] and in India in larger proportions [48]. However, the increase in the hybridization phenomenon between these two strains has been suggested in several studies [51] [54], precisely because EAEC can integrate other virulence genes in order to generate epidemic isolates [55], this emphasizes the fact that this phenomenon is expanding and therefore it would be wise to implement monitoring methods.

The absence of identification of EIEC isolates $(0.0 \%)$ in this study is perfectly in line with the literature that reports a weak prevalence of this class of DEC in young children [9] [40]. Indeed, they are known to cause diarrheal symptoms similar to those of Shigella in adults and children sometimes associated with malnutrition [7] [56]. The registered results are similar to those found in India $(1.0 \%)$, Iran (0.7\%), Nigeria (0.6\%), Kenya (0.6\%), Libya (0\%), and Gabon (0\%) [9] [24] [32] [41] [42] [44].

\subsection{Different Genes of Intra-Pathovar Determinants and Classification of DEC}

The characterization of virulence factors not only makes it possible to classify the different pathotypes of the $E$. coli strains, but also these factors are of particular interest as potential targets in therapeutic and/or vaccine trials [57]. For the ETEC pathotype, the prevalence of the enterotoxin $S T$ gene was highest and there were no isolates combining both enterotoxin types in this study. This profile is comparable to that obtained by Saka et al., in Nigeria [58], from Cabal et al., in Spain [59], and other studies [25] [57]. Although, in the latter ones isolates combining the two types of enterotoxins were found

The low prevalence of verocytotoxic O157 EHEC isolates in developing countries makes epidemiological characterization of circulating strains difficult [43]. However, the verocytoxin vit2 gene and the combination of both types were the most common genetic markers in the EHEC pathogen in this study. This profile is similar to previous studies [20] [57]. In addition, the virulence markers of the 
EHEC island-O like shiga toxins (stx/vt) marked by a high diversity of variants of this family [7] [32]. Virulence factor stx2/vt2 is most frequently reported in the literature [44] [60] corroborating the results of this study on the most recurring virulence determinant.

EPEC is one of the most frequently isolated DEC pathotypes in developing countries, particularly in children under 2 years of age [46] [47] [61]. Current advances in their characterization demonstrate the emergence of atypical strains (aEPEC) in addition to the so-called typical strains [50] [62]. The EPEC strains detected in this study were all typical EPEC and were significantly higher in children with diarrhea than in controls. Their high prevalence compared to atypical would be the fact that they are still prevalent in the poor regions of sub-Saharan Africa [63] [64] while atypical are predominant in developed countries [65]. Our results are in agreement with those reported by Saka and collaborators in Nigeria [58]. But, different from those found by Zhou et al., in China, Singh et al., in India and Darbandi et al., in Iran who reported aEPEC prevalences of $77.8 \% ; 20.0 \%$, and 39,0\%, respectively, [25] [46] [64].

\subsection{Comparison between Phenotypic and Molecular Detection}

The E. coli O157: $\mathrm{H7}$ serotype is the main agent implicated in hemorrhagic diarrhea, the molecular characteristic is the presence of the genes coding for a shiga-toxin (stx) by these so-called STEC strains and the capacity for attachment and effacement induced by intimin, an adhesion receptor encoded by the eae $A$ gene [66] [67]. Although 63.5\% of strains had phenotypic characteristics, no PCR detection of associated genetic markers coding for the stx 1 and stx 2 variants associated with the eae gene was recorded in this study. Our results are different from several studies that found high levels of $s t x$ genes [44] [68]. However, $28.3 \%$ of the strains were carriers of the vit 1 and vit 2 genes coding for verocytotoxins whose O157 serotype is also one of the E. coli strains producing verocytotoxins known to be harmful to humans [69]. The strong presence of this serotype of DEC suggests that the origin of diarrhea is food. Indeed, an incidence of 801 cases of foodborne E. coli O157 infection in the province of Alberta in Canada was estimated by the public health database [60] and the Centers for Disease Control and Prevention estimated that in the United States, E. coli O157: H7 causes more than 63,000 cases per year, resulting in more than 2100 hospitalizations and 20 deaths [67]. The rural nature of the study city, consumption of local and imported meats, stream water would contribute to the high rate of $E$. coli $\mathrm{O} 157$ recorded.

\subsection{Classification of $\beta$-Lactamases by Diarrheagenic $E$. coli}

The expansion of antibiotic resistance, particularly in enteric isolates in developing countries, is of great concern, and an improvement in our knowledge of the different susceptibility profiles in the latter is essential [70] [71]. Literature reports many cases of multiresistant DEC strains [14] [61] [72] [73]. The phe- 
notypic characterization of the possible resistance mechanisms responsible for the multidrug resistance observed in the DEC of this study reveals significant levels of isolates producing carbapenemase type $\beta$-lactamases (31.7\%), extended spectrum $\beta$-lactamases (ESBL) (24.4\%) and the ESBL-cephalosporinases association (17.1\%). Indeed, previous studies on the analysis of multidrug resistance phenotypes of DEC certainly favor the production of various ESBLs with variable prevalences; however, other $\beta$-lactamases are also involved. In Burkina-Faso, a study revealed $38.7 \%$ of DEC-ESBL, $6.4 \%$ DEC-ESBL + Case and 9.7\% DECESBL + carbapenemases [5]. In India, Mandal et al. reported a DEC-ESBL prevalence of $37.6 \%$ of [74], while two different studies in Iran reported prevalences of $43.8 \%$ [73] and $69.2 \%$ [75], comparable to that found in our study. However, the ETEC pathotype was the most common producer of ESBL, a profile similar to other studies [57] [74]. The frequency of carbapenemases recorded in this study, particularly for EPEC, ETEC and EHEC pathotypes, is likely related to the current pattern of $E$. coli enzyme release in Enterobacteriaceae. In addition, this diversity of $\beta$-lactamases could be the consequence of horizontal transfer of resistance and virulence genes involving mobile genetic elements such as resistance plasmids and class 1 integuments [76] [77] which contribute to the increase of new pathogens and their multiresistance.

\subsection{Limitations of the Study}

The data from this study do not allow for clear profiling of the different pathovars of circulating $E$. coli. In addition, the low detection of DEC in control children, probably correlated with the sample size, does not allow a strict distinction between strains with high clinical importance and those with minor clinical importance.

\section{Conclusion}

The results of this study demonstrate the prevalence of different of diarrheagenic E. coli pathotypes, particularly EHEC and ETEC, are highly correlated with childhood diarrhea in the city of Koula-Moutou. However, the detection of EHEC and ETEC strains in apparently healthy children would indicate that they could then be sources of transmission of these pathogens to other children. This study also shows that virulence genes associated with different $E$. coli pathotype can coexist in the same strains. Ultimately, this study demonstrates the high prevalence of DEC in rural areas, the development of new hybrid DEC strains and those producing ESBL and carbapenemase $\beta$-lactamases. This could be a new risk factor for morbidity and mortality among young children in developing countries, and could challenge traditional diagnoses of $E$. coli infections, thereby increasing the risk of therapeutic deadlock.

\section{Author Contributions}

All authors contributed to the study conception and design. Material prepara- 
tion, data collection and analysis were performed by Rolande Mabika Mabika, Jean Fabrice Yala, Franck Mounioko and Sandrine Lydie Oyegue Liabagui. The first draft of the manuscript was written by Rolande Mabika Mabika, Jean Fabrice Yala, Hilaire Kenguele Moundounga, Alain SOUZA and all authors commented on previous versions of the manuscript. All authors read and approved the final manuscript.

\section{Conflicts of Interest}

The authors declare that there is no conflict of interest regarding the publication of this paper.

\section{References}

[1] OMS (2017) Maladies diarréhiques. http://www.who.int/fr/news-room/fact-sheets/detail/diarrhoeal-disease

[2] Ateudjieu, J., Bita'a Beyala, L., Guenou, E., Chebe, A.N., Chukuwchindun, B.A., Goura, A.P., et al. (2018) Profil et antibiosensibilité des bactéries pathogènes associées aux diarrhées chez les patients consultants à l'Hôpital Régional Annexe de Kousseri, Extrême-Nord Cameroun. The Pan African Medical Journal, 29, 1-12. https://doi.org/10.11604/pamj.2018.29.170.14296

[3] Dias, R.C.B., Dos Santos, B.C., Dos Santos, L.F., Vieira, M.A., Yamatogi, R.S., Mondelli, A.L., et al. (2016) Diarrheagenic Escherichia coli Pathotypes Investigation Revealed Atypical Enteropathogenic E. coli as Putative Emerging Diarrheal Agents in Children Living in Botucatu, Sâo Paulo State, Brazil. Acta Pathologica, Microbiologica, et Immunologica Scandinavica, 124, 299-308. https://doi.org/10.1111/apm.12501

[4] Stewart, C.C. (2001) Diarrhoeagenic Escherichia coli an Emerging Problem? Diagnostic Microbiology and Infectious Disease, 41, 93-98. https://doi.org/10.1016/S0732-8893(01)00303-0

[5] Konaté, A., Dembélé, R., Guessennd, N., Kouadio, F.K. and Kouadio, I.K. (2017) Epidemiology and Antibiotic Resistance Phenotypes of Diarrheagenic Escherichia coli Responsible for Infantile Gastroenteritis in Ouagadougou, Burkina Faso. European Journal of Microbiology and Immunology, 7, 168-175. https://doi.org/10.1556/1886.2017.00014

[6] Ramya Raghavan, P., Roy, S., Thamizhmani, R. and Sugunan, A.P. (2017) Diarrheagenic Escherichia coli Infections among the Children of Andaman Islands with Special Reference to Pathotype Distribution and Clinical Profile. Journal of Epidemiology and Global Health, 7, 305-308. https://doi.org/10.1016/j.jegh.2017.07.003

[7] Gomes, T.A.T., Elias, W.P., Scaletsky, I.C.A., Guth, B.E.C., Rodrigues, J.F., Piazza, R.M.F., et al. (2016) Diarrheagenic Escherichia coli. Brazilian Journal of Microbiology, 47, 3-30. https://doi.org/10.1016/j.bjm.2016.10.015

[8] Nyholm, O., Halkilahti, J., Wiklund, G., Okeke, U. and Paulin, L. (2015) Comparative Genomics and Characterization of Hybrid Shigatoxigenic and Enterotoxigenic Escherichia coli (STEC/ETEC) Strains. PLoS ONE, 10, e0135936.

https://doi.org/10.1371/journal.pone.0135936

[9] Onanuga, A., Igbeneghu, O. and Lamikanra, A. (2014) A Study of the Prevalence of Diarrhoeagenic Escherichia coli in Children from Gwagwalada, Federal Capital Territory, Nigeria. The Pan African Medical Journal, 17, 146.

https://doi.org/10.11604/pamj.2014.17.146.3369 
[10] Odetoyin, B.W., Hofmann, J., Aboderin, A.O. and Okeke, I.N. (2016) Diarrhoeagenic Escherichia coli in Mother-Child Pairs in Ile-Ife, South Western Nigeria. BMC Infectious Diseases, 16, Article No. 28. https://doi.org/10.1186/s12879-016-1365-X

[11] Natarajan, M., Kumar, D., Mandal, J., Biswal, N. and Stephen, S. (2018) A Study of Virulence and Antimicrobial Resistance Pattern in Diarrhoeagenic Escherichia coli Isolated from Diarrhoeal Stool Specimens from Children and Adults in a Tertiary Hospital, Puducherry, India. Journal of Health, Population and Nutrition, 37, Article No. 17. https://doi.org/10.1186/s41043-018-0147-Z

[12] Alikhani, M.Y., Hashemi, S.H., Aslani, M.M. and Farajnia, S. (2013) Prevalence and Antibiotic Resistance Patterns of Diarrheagenic Escherichia coli Isolated from Adolescents and Adults in Hamedan, Western Iran. Iranian Journal of Microbiology, 5, 42-47.

[13] Chen, Y., Chen, X., Yu, F., Wu, M., Wang, R., Zheng, S., et al. (2016) Serology, Virulence, Antimicrobial Susceptibility and Molecular Characteristics of Clinical $\mathrm{Vi}$ brio parahaemolyticus Strains Circulating in Southeastern China from 2009 to 2013. Clinical Microbiology and Infection, 22, 52-58. https://doi.org/10.1016/j.cmi.2015.11.003

[14] Canizalez-Roman, A., Flores-Villaseñor, H.M., Gonzalez-Nuñez, E., VelazquezRoman, J., Vidal, J.E., Muro-Amador, S., et al. (2016) Surveillance of Diarrheagenic Escherichia coli Strains Isolated from Diarrhea Cases from Children, Adults and Elderly at Northwest of Mexico. Frontiers in Microbiology, 7, 1924.

https://doi.org/10.3389/fmicb.2016.01924

[15] Scallan, E., Hoekstra, R.M., Angulo, F.J., Tauxe, R.V., Widdowson, M.-A., Roy, S.L., et al. (2011) Foodborne Illness Acquired in the United States-Major Pathogens. Emerging Infectious Diseases, 17, 1338-1340. https://doi.org/10.3201/eid1701.P21101

[16] Massot, M., Picard, B. and Denamur, E. (2016) Diversité des populations d'Escherichia coli et leurs variations au cours du temps au sein du microbiote intestinal. Revue Francophone des Laboratoires, 486, 35-43. https://doi.org/10.1016/S1773-035X(16)30326-4

[17] Croxen, M.A., Law, R.J., Scholz, R., Keeney, K.M., Wlodarska, M. and Finlay, B.B. (2013) Recent Advances in Understanding Enteric Pathogenic Escherichia coli. Clinical Microbiology Reviews, 26, 822-880. https://doi.org/10.1128/CMR.00022-13

[18] Mabika Mabika, R.M., Oyegue-Liabagui, S.L., Mounioko, F., Dibakou, S.E., Mongo Delis, A., Moussavou, M.G., et al. (2021) Etiology and Biodistribution of Enterobacteria and Parasites, among Children under 5 Years Old with Diarrhea in EastCentral Gabon. Annals of Clinical and Medical Microbiology, 5, 1-13. https://doi.org/10.21203/rs.3.rs-131619/v1

[19] Jafari, F., Garcia-Gil, L.J., Salmanzadeh-Ahrabi, S., Shokrzadeh, L., Aslani, M.M., Pourhoseingholi, M.A., et al. (2018) Diagnosis and Prevalence of Enteropathogenic Bacteria in Children Less than 5 Years of Age with Acute Diarrhea in Tehran Children's Hospitals. Journal of Infection, 58, 21-27.

https://www.sciencedirect.com/science/article/pii/S016344530800368X https://doi.org/10.1016/j.jinf.2008.10.013

[20] Vilchez, S., Reyes, D., Paniagua, M., Bucardo, F., Mo, R. and Weintraub, A. (2009) Prevalence of Diarrhoeagenic Escherichia coli in Children from Leon, Nicaragua. Journal of Medical Microbiology, 58, 630-637. https://doi.org/10.1099/jmm.0.007369-0

[21] Lluque, A., Mosquito, S., Gomes, C., Riveros, M., Durand, D., Tilley, D.H., et al. (2015) Virulence Factors and Mechanisms of Antimicrobial Resistance in Shigella 
Strains from Periurban Areas of Lima (Peru). Journal of Medical Microbiology, 305, 480-490. https://doi.org/10.1016/j.ijmm.2015.04.005

[22] Jafari, F., Shokrzadeh, L., Hamidian, M., Salmanzadeh-Ahrabi, S. and Zali, M.R. (2008) Acute Diarrhea Due to Enteropathogenic Bacteria in Patients at Hospitals in Tehran. Japanese Journal of Infectious Diseases, 61, 269-273.

[23] Robin, F., Gibold, L. and Bonnet, R. (2012) Résistances naturelles et acquises aux $\beta$-lactamines chez les entérobactéries: Comment les identifier en pratique quotidienne? Revue Francophone des Laboratoires, 445, 47-58. https://doi.org/10.1016/S1773-035X(12)71676-3

[24] Iijima, Y., Oundo, J.O., Hibino, T., Saidi, S.M., Hinenoya, A., Osawa, K., et al. (2017) High Prevalence of Diarrheagenic Escherichia coli among Children with Diarrhea in Kenya. Japanese Journal of Infectious Diseases, 70, 80-83. https://doi.org/10.7883/yoken.JID.2016.064

[25] Darbandi, A., Owlia, P., Bouzari, S. and Saderi, H. (2016) Diarrheagenic Escherichia coli Pathotypes Frequency in Khuzestan Province of Iran. Iranian Journal of Microbiology, 8, 352-358.

[26] Somda, Bonkoungou, N.S., Zongo, O.J.I., Kpoda, C., Tapsoba, D.S., Bassolé, F., et al. (2017) Prevalence of Escherichia coli Virulence Genes in Patients with Diarrhoea in Ouagadougou, Burkina Faso. African Journal of Clinical and Experimental Microbiology, 18, 179-185. https://doi.org/10.4314/ajcem.v18i4.1

[27] Clarke, S.C., Haigh, R.D., Freestone, P.P.E. and Williams, P.H. (2003) Virulence of Enteropathogenic Escherichia coli, a Global Pathogen. Clinical Microbiology Reviews, 16, 365-378. https://doi.org/10.1128/CMR.16.3.365-378.2003

[28] Trabulsi, L.R., Keller, R. and Gomes, T.A.T. (2002) Typical and Atypical Enteropathogenic Escherichia coli. Emerging Infectious Diseases, 8, 508-513. https://doi.org/10.3201/eid0805.010385

[29] Murongo Kanyande, A. (2017) Bilan épidémiologique des maladies diarrhéiques d'origine hydro-fécale dans la zone de santé rurale de Walikale. Annales de P UNIGOM, 7, 349-362.

[30] Djourdebbé, F.B. (2019) Santé Environnementale dans les villes en Afrique Subsaharienne: Problèmes conceptuels et méthodologiques. European Scientific Journal, 15, 192-213. https://doi.org/10.19044/esj.2019.v15n9p192

[31] Aijuka, M., Santiago, A.E., Girón, J.A., Naturo, J.P. and Buys, E.M. (2018) Enteroaggregative Escherichia coli Is the Predominant Diarrheagenic E. coli Pathotype among Irrigation Water and Food Sources in South Africa. International Journal of Food Microbiology, 278, 44-51. https://doi.org/10.1016/j.ijfoodmicro.2018.04.018

[32] Makobe, C.K., Sang, W.K., Kikuvi, G. and Kariuki, S. (2012) Molecular Characterization of Virulence Factors in Escherichia coli Isolates from Children in Nairobi, Kenya. Journal of Infection in Developing Countries, 6, 598-604. https://doi.org/10.3855/jidc.2082

[33] Presterl, E., Zwick, R.H., Reichmann, S., Aichelburg, A., Winkler, S., Kremsner, P.G., et al. (2003) Frequency and Virulence Properties of Diarrheagenic Escherichia coli in Children with Diarrhea in Gabon. American Journal of Tropical Medicine and Hygiene, 69, 406-410. https://doi.org/10.4269/ajtmh.2003.69.406

[34] Koko, J., Ategbo, S. and Gahouma, D. (2013) Epimiologie des diarrhées aiguës bactériennes de l'enfant à Libreville, Gabon. Archives de Pédiatrie, 30, 1-2.

https://doi.org/10.1016/j.arcped.2013.01.017

[35] Bonkoungou, I.O., Haukka, K., Österblad, M., Hakanen, A.J., Traoré, A.S., Barro, N., et al. (2013) Bacterial and Viral Etiology of Childhood Diarrhea in Ouagadou- 
gou, Burkina Faso. BMC Pediatrics, 13, 36. https://doi.org/10.1186/1471-2431-13-36

[36] Abdel-Hafeez, E.H., Belal, U.S., Abdellatiff, M.Z.M., Naoi, K. and Norose, K. (2013) Breast-Feeding Protects Infantile Diarrhea Caused by Intestinal Protozoan Infections. The Korean Journal of Parasitology, 51, 519-524. https://doi.org/10.3347/kjp.2013.51.5.519

[37] Gertosio, C., Meazza, C., Pagani, S. and Bozzola, M. (2016) Breastfeeding and Its Gamut of Benefits. Minerva Pediatrics, 68, 201-212.

[38] Trainor, E., Iturriza-Gomara, M., Ngwira, B. and Cunliffe, N. (2015) Detection of Enterotoxigenic E. coli in Hospitalised Children with and without Diarrhoea in Blantyre, Malawi. Paediatrics and International Child Health, 36, 102-105. https://doi.org/10.1080/20469047.2015.1109245

[39] Mansour, A., Shaheen, H.I., Amine, M., Hassan, K., Sanders, J.W., Riddle, M.S., et al. (2014) Pathogenicity and Phenotypic Characterization of Enterotoxigenic Escherichia coli Isolates from a Birth Cohort of Children in Rural. Journal of Clinical Microbiology, 52, 587-591. https://doi.org/10.1128/JCM.01639-13

[40] Verma, S., Venkatesh, V., Kumar, R., Kashyap, S., Kumar, M., Maurya, A.K., et al. (2019) Etiological Agents of Diarrhea in Hospitalized Pediatric Patients with Special Emphasis on Diarrheagenic. Journal of Laboratory Physicians, 11, 68-74. https://doi.org/10.4103/JLP.JLP $123 \quad 18$

[41] Ochoa, T.J., Ruiz, J., Molina, M., Valle, L.J., Gil, A.I., et al. (2009) High Frequency of Antimicrobial Drug Resistance of Diarrheagenic Escherichia coli in Infants in Peru. American Journal of Tropical Medicine \& Hygiene, 81, 296-301. https://doi.org/10.4269/ajtmh.2009.81.296

[42] Ali, M.M.M., Mohamed, Z.K., Klena, J.D., Ahmed, S.F., Moussa, T.A.A. and Ghenghesh, K.S. (2012) Molecular Characterization of Diarrheagenic Escherichia coli from Libya. American Journal of Tropical Medicine and Hygiene, 86, 866-871. https://doi.org/10.4269/ajtmh.2012.11-0330

[43] Nyanga, P.L., Onyuka, J., Webale, M.K., Were, T. and Budambula, V. (2017) Escherichia coli Pathotypes and Shigella Serogroups in Diarrheic Children in Nairobi City, Kenya. Gastroenterology and Hepatology from Bed to Bench, 10, 220-228.

[44] Falup-Pecurariu, O., Lixandru, R.I., Cojocaru, E., Csutak, K., Monescu, V., Muhsen, K., et al. (2019) Shiga Toxin Producing Escherichia coli-Associated Diarrhea and Hemolytic Uremic Syndrome in Young Children in Romania. Gut Pathogens, 11, Article No. 46. https://doi.org/10.1186/s13099-019-0327-4

[45] Rajendran, P., Ajjampur, S.S.R., Chidambaram, D., Chandrabose, G., Thangaraj, B., Sarkar, R., et al. (2010) Pathotypes of Diarrheagenic Escherichia coli in Children Attending a Tertiary Care Hospital in South India. Diagnostic Microbiology and Infectious Disease, 68, 117-122. https://doi.org/10.1016/j.diagmicrobio.2010.06.003

[46] Zhou, Y., Zhu, X., Hou, H., Lu, Y., Yu, J., Mao, L., et al. (2018) Characteristics of Diarrheagenic Escherichia coli among Children under 5 Years of Age with Acute Diarrhea: A Hospital Based Study. BMC Infectious Diseases, 18, Article No. 63. https://doi.org/10.1186/s12879-017-2936-1

[47] Shetty, V.A., Kumar, S.H., Shetty, A.K., Karunasagar, I. and Karunasagar, I. (2012) Prevalence and Characterization of Diarrheagenic Escherichia coli Isolated from Adults and Children in Mangalore, India. Journal of Laboratory Physicians, 4, 24-29. https://doi.org/10.4103/0974-2727.98666

[48] Dutta, S., Guin, S., Ghosh, S., Pazhani, G.P., Rajendran, K., Bhattacharya, M.K., et al. (2013) Trends in the Prevalence of Diarrheagenic Escherichia coli among Hospitalized Diarrheal Patients in Kolkata. PLoS ONE, 8, e56068. 
https://doi.org/10.1371/journal.pone.0056068

[49] Okeke, I.N. (2009) Diarrheagenic Escherichia coli in Sub-Saharan Africa: Status, Uncertainties and Necessities. Journal of Infection in Developing Countries, 3, 817 842. https://doi.org/10.3855/jidc.586

[50] Hu, J. and Torres, A.G. (2015) Enteropathogenic Escherichia coli: Foe or Innocent Bystander? Clinical Microbiology and Infection, 21, 729-734. https://doi.org/10.1016/j.cmi.2015.01.015

[51] Nyholm, O., Heinikainen, S., Pelkonen, S., Hallanvuo, S., Haukka, K. and Siitonen, A. (2015) Hybrids of Shigatoxigenic and Enterotoxigenic Escherichia coli (STEC/ ETEC) among Human and Animal Isolates in Finland. Zoonoses Public Health, 62, 518-524. https://doi.org/10.1111/zph.12177

[52] Bibbal, D., Auvray, F., Kerouredan, M., Peytavin, C., Ferre, F., Cartier, P., et al. (2012) Prévalence des Escherichia coli entérohémorragiques (EHEC) O157:H7, O26:H11, O103:H2, O145:H28 et O111:H8 dans le troupeau bovin en France. Rencontres autour des Recherches sur les Ruminants, 19, 107-110.

[53] Bouzari, S., Farhang, E., Hosseini, S.M. and Alikhani, M.Y. (2018) Prevalence and Antimicrobial Resistance of Shiga Toxin-Producing Escherichia coli and Enteropathogenic Escherichia coli Isolated from Patients with Acute Diarrhea. Iranian Journal of Microbiology, 10, 151-157.

[54] Borgatta, B., Kmet-Lunacek, N. and Rello, J. (2012) E. coli O104:H4 Outbreak and Haemolytic-Uraemic Syndrome. Medicina Intensiva, 36, 576-583.

https://doi.org/10.1016/j.medin.2011.11.022

[55] Chen, Y., Chen, X., Zheng, S., Yu, F., Kong, H., Yang, Q., et al. (2013) Serotypes, Genotypes and Antimicrobial Resistance Patterns of Human Diarrhoeagenic Escherichia coli Isolates Circulating in Southeastern China. Clinical Microbiology and Infection, 20, 52-58. https://doi.org/10.1111/1469-0691.12188

[56] van den Beld, M.J.C., Warmelink, E., Friedrich, A.W., Reubsaet, F.A.G., Schipper, M., de Boer, R.F., et al. (2019) Incidence, Clinical Implications and Impact on Public Health of Infections with Shigella spp. and Entero-Invasive Escherichia coli (EIEC): Results of a Multicenter Cross-Sectional Study in the Netherlands during 2016-2017. BMC Infectious Diseases, 19, Article No. 1037. https://doi.org/10.21203/rs.2.14336/v2

[57] Margulieux, K.R., Srijan, A., Ruekit, S., Nobthai, P., Poramathikul, K., Pandey, P., et al. (2018) Extended-Spectrum $\beta$-Lactamase Prevalence and Virulence Factor Characterization of Enterotoxigenic Escherichia coli Responsible for Acute Diarrhea in Nepal from 2001 to 2016. Antimicrobial Resistance \& Infection Control, 7, Article No. 87. https://doi.org/10.1186/s13756-018-0377-2

[58] Saka, H.K., Dabo, N.T., Muhammad, B. and García-Soto, S. (2019) Diarrheagenic Escherichia coli Pathotypes from Children Younger than 5 Years in Kano State, Nigeria. Frontiers in Microbiology, 7, 34. https://doi.org/10.3389/fpubh.2019.00348

[59] Cabal, A., García-castillo, M., Cantón, R., Gortázar, C., Domínguez, L. and Álvarez, J. (2016) Prevalence of Escherichia coli Virulence Genes in Patients with Diarrhea and a Subpopulation of Healthy Volunteers in Madrid, Spain. Frontiers in Microbiology, 7, Article No. 641. https://doi.org/10.3389/fmicb.2016.00641

[60] Lisboa, L.F., Szelewicki, J., Lin, A., Latonas, S., Li, V., Zhi, S., et al. (2016) Epidemiology of Shiga Toxin-Producing Escherichia coli O157 in the Province of Alberta, Canada, 2009-2016. Toxins (Basel), 11, Article No. 613. https://doi.org/10.3390/toxins11100613

[61] Gebresilasie, Y.M., Tullu, K.D. and Yeshanew, A.G. (2018) Resistance Pattern and 
Maternal Knowledge, Attitude and Practices of Suspected Diarrheagenic Escherichia coli among Children under 5 Years of Age in Addis Ababa, Ethiopia: Cross Sectional Study. Antimicrobial Resistance \& Infection Control, 7, Article No. 110. https://doi.org/10.1186/s13756-018-0402-5

[62] Chellapandi, K., Dutta, T.K., Sharma, I., De Mandal, S., Kumar, N.S. and Ralte, L. (2017) Prevalence of Multi Drug Resistant Enteropathogenic and Enteroinvasive Escherichia coli Isolated from Children with and without Diarrhea in Northeast Indian Population. Annals of Clinical Microbiology and Antimicrobials, 16, Article No. 49. https://doi.org/10.1186/s12941-017-0225-x

[63] Bakhshi, B., Fallahzad, S. and Pourshafie, M.R. (2012) The Occurrence of Atypical Enteropathogenic Escherichia coli Strains among Children with Diarrhea in Iran. Journal of Infection and Chemotherapy, 19, 615-620.

[64] Singh, T., Das, S., Ramachandran, V.G., Shah, D., Saha, R. and Dar, S.A. (2017) Typical \& Atypical Enteropathogenic Escherichia coli in Diarrhoea \& Their Role as Carrier in Children under Five. Indian Journal of Medical Research, 145, 551-557.

[65] Santona, S., Diaz, N., Fiori, P.L., Francisco, M., Sidat, M., Cappuccinelli, P., et al. (2013) Genotypic and Phenotypic Features of Enteropathogenic Escherichia coli Isolated in Industrialized and Developing Countries. Journal of Infection in Developing Countries, 7, 214-219. https://doi.org/10.3855/jidc.3054

[66] Clements, A., Young, J.C., Constantinou, N. and Frankel, G. (2012) Infection Strategies of Enteric Pathogenic Escherichia coli. Gut Microbes, 3, 71-87. https://doi.org/10.4161/gmic.19182

[67] Saxena, T., Kaushik, P. and Krishna, M.M. (2015) Prevalence of E. coli O157:H7 in Water Sources: An Overview on Associated Diseases, Outbreaks and Detection Methods. Diagnostic Microbiology and Infectious Disease, 82, 249-264.

https://doi.org/10.1016/j.diagmicrobio.2015.03.015

[68] Carroll, K.J., Harvey-vince, L., Jenkins, C., Mohan, K. and Balasegaram, S. (2019) The Epidemiology of Shiga Toxin-Producing Escherichia coli Infections in the South East of England: November 2013-March 2017 and Significance for Clinical and Public Health. Journal of Medical Microbiology, 68, 930-939. https://doi.org/10.1099/jmm.0.000970

[69] Bardiau, M., Szalo, M. and Mainil, J. (2010) Initial Adherence of EPEC, EHEC and VTEC to Host Cells. Veterinary Research, 41, Article No. 57. https://doi.org/10.1051/vetres/2010029

[70] Randrianirina, F., Ratsima, E.H., Ramparany, L., Randremanana, R., Rakotonirina, H.C., Andriamanantena, T., et al. (2014) Antimicrobial Resistance of Bacterial Enteropathogens Isolated from Stools in Madagascar. BMC Infectious Diseases, 14, Article No. 104. https://doi.org/10.1186/1471-2334-14-104

[71] Benmessaoud, R., Nezha, M., Moraleda, C., Jroundi, I., Houssain, T., Pons, M.J., et al. (2016) Antimicrobial Resistance Levels among Diarrhoeagenic Micro-Organisms Recovered from Children under-5 with Acute Moderate-to-Severe Diarrhoea in Rabat, Morocco. Journal of Global Antimicrobial Resistance, 7, 34-36. https://doi.org/10.1016/j.jgar.2016.07.005

[72] Eltai, N.O., Thani, A.A., Hadidi, S.H., Ansari, K. and Yassine, H.M. (2020) Antibiotic Resistance and Virulence Patterns of Pathogenic Escherichia coli Strains Associated with Acute Gastroenteritis among Children in Qatar. BMC Microbiology, 20, Article No. 54. https://doi.org/10.1186/s12866-020-01732-8

[73] Karami, P., Bazmamoun, H., Sedighi, I., Sasan, A. and Nejad, M. (2017) Antibacterial Resistance Patterns of Extended Spectrum $\beta$-Lactamase-Producing Entero- 
pathogenic Escherichia coli Strains Isolated from Children. Arab Journal of Gastroenterology, 18, 206-209. https://doi.org/10.1016/j.ajg.2017.11.004

[74] Mandal, A., Sengupta, A., Kumar, A., Singh, U.K., Jaiswal, A.K., Das, P., et al. (2017) Molecular Epidemiology of Extended-Spectrum $\beta$-Lactamase-Producing Escherichia coli Pathotypes in Diarrheal Children from Low Socioeconomic Status Communities in Bihar, India: Emergence of the CTX-M Type. Infectious Diseases: Research and Treatment, 10, 1-11. https://doi.org/10.1177/1178633617739018

[75] Sheikh, A.F., Moosavian, M., Abdi, M., Heidary, M., Shahi, F., Jomehzadeh, N., et al. (2019) Prevalence and Antimicrobial Resistance of Shigella Species Isolated from Diarrheal Patients in Ahvaz, Southwest Iran. Infection and Drug Resistance, 12, 249-253. https://doi.org/10.2147/IDR.S187861

[76] Ahumada-Santos, Y.P., Báez-fFores, M.E., Díaz-Camacho, S.P., Uribe-Beltrán, M.J., Eslava-Campos, C.A., Parra-Unda, J.R., et al. (2019) Association of Phylogenetic Distribution and Presence of Integrons with Multidrug Resistance in Escherichia coli Clinical Isolates from Children with Diarrhoea. Journal of Infection and Public Health, 13, 767-772.

[77] Kubomura, A., Sekizuka, T., Onozuka, D., Murakami, K., Kimura, H., Sakaguchi, M., et al. (2020) Truncated Class 1 Integron Gene Cassette Arrays Contribute to Antimicrobial Resistance of Diarrheagenic Escherichia coli. BioMed Research International, 2020, Article ID: 4908189. https://doi.org/10.1155/2020/4908189 